\title{
Att skriva vägen till Santiago
}

\author{
LENA GEMZÖE
}

Sedan början av 2000-talet har intresset för pilgrimsvandringar till den medeltida vallfärdsorten Santiago de Compostela ökat markant i Sverige, vilket bland annat visar sig i mängden av text som produceras om fenomenet. I den här artikeln analyseras tre litterära skildringar av Santiago-vallfärden, vilka kan infogas $i$ en cirkularitet av skrivande, berättande och resande som kännetecknar pilgrimskulturen. Kan pilgrimsvandringar ses som uttryck för ureligionens återkomst" och vad kan de i så fall säga oss om en sådan återkomst?

Tanken att religion i början på 2000-talet fått en förnyad betydelse som politisk och moralisk kraft är sedan ett antal år tillbaka föremål för ett stort intresse bland samhällsdebattörer, politiker och forskare. Samhällsvetenskaperna, som tills helt nyligen i stort sett ignorerade religion som studieobjekt, har ställts inför uppgiften att försöka förstå innebörden i det som kallats den post-sekulära vändningen eller religionens återkomst. För att bidra till en sådan förståelse startade det europeiska forskningsorganet Norface 2007 ett större pro-

Lena Gemzöe, docent, Centrum för genusstudier, Stockholms universitet. gram på temat med fokus på Europa. ${ }^{1}$ Tillsammans med antropologer från Irland och Nederländerna utför jag inom det här programmet en socialantropologisk delstudie. Vi riktar intresset mot ett fenomen som mer sällan förekommer i debatter om religionens återkomst, nämligen pilgrimsresande. Medan deltagandet i kyrkosamfundens aktiviteter överlag visat på en stadig

1 "Reemergence of religion as a social force in Europe?" Norface, European Science Foundation. Som frågetecknet antyder arbetar forskarna med öppna frågeställningar, inte minst i förhållande till nyckelbegreppen "religion", "återkomst» och "social kraft» som alla måste preciseras och prövas i empiriska studier. 
nedgång sedan lång tid tillbaka $\mathrm{i}$ Europa (McLeod \& Ustorf 2005) har forskare noterat en intensifiering av pilgrimsresandet $\mathrm{i}$ Europa, och världen (Badone \& Roseman 2004, Coleman \& Eade 2004, Dubisch \& Winkelman 2005).

Vårt projekt rör de meningsskapande dimensionerna av pilgrimsresande: vilka betydelser tillskrivs pilgrimsresor av institutioner och kyrkor, turistnäring och medier samt av pilgrimerna själva? ${ }^{2}$ I min studie studerar jag konstruktionen av mening i pilgrimsresande till Santiago de Compostela från svensk utgångspunkt. Resandekulturen studeras med multilokalt etnografiskt fältarbete, intervjuer av pilgrimer och andra aktörer samt analys av kulturellt material i medietexter, däribland böcker. I den här artikeln riktar jag ett särskilt fokus på en aspekt av det svenska intresset för pilgrimsresande: tre skildringar av vandringar på vägen till Compostela publicerade åren 2003, 2005 och 2006.

\section{Bakgrund}

Det nutida pilgrimsresandet till en av de äldsta och mest välkända kristna vallfartsorterna, Santiago de Compostela i spanska Galicien, tycks utgöra ett illustrativt exem-

2 I projektet Gender, nation and religiousdiversity in force at European pilgrimage sites studeras pilgrimsfenomenet i Europa av en forskargrupp på sju personer med multilokal deltagande observation (lokal kontext, resvägar, vallfärdsorterna), djupintervjuer, digital dokumentation och textanalys. pel på religionens återkomst i Europa. Tiotusentals pilgrimer vandrar varje år, några cyklar, längs den drygt sju hundra kilometer långa medeltida pilgrimsled som går genom norra Spanien fram till slutmålet i Europas västligaste ände: katedralen i Santiago de Compostela. ${ }^{3}$ Enligt legenden hyser katedralen aposteln Jakobs grav. Antalet pilgrimer ökar stadigt och i en allt snabbare takt sedan 1980-talet. De övernattar i sovsalar i enkla härbärgen längs vägen och många bär den vandringsstav och mussla som är Sankt Jakobs symboler. Väl framme i Santiago, efter en månads vandring för dem som gått hela vägen, deltar de flesta pilgrimer $i$ ankomstritualerna i katedralen. Man köar för att komma in och omfamna den staty av Sankt Jakob som är placerad bakom altaret. Många deltar också i firandet av Pilgrimsmässan där namn och nationalitet på varje nyanländ pilgrim läses upp. I predikningarna betonar prästerna den katolska kyrkans roll att samla kristna från olika kyrkor och nationer.

Studier av den moderna vallfärden till Santiago visar emellertid att det som antar formen av traditionell katolsk helgonkult är en i högsta grad heterogen och heterodox företeelse (Frey 1998, Roseman 2004, Egan kommande). Vallfärden har gradvis fått en alltmer internationell prägel, pilgrimerna kommer från hela Europa, men även från en rad länder i andra världsdelar, särskilt USA och Brasilien. Den amerikanska socialantropologen Nancy Frey beskriver i sin

3 De flesta vandrar den så kallade franska leden, men vägen till Santiago består av olika vägar som alla leder till Santiago de Compostela, samt av anslutande vägar från angränsande europeiska länder och Spaniens inland. 
studie som bygger på ett omfattande antropologiskt fältarbete längs vägen under 1990talet, hur religiöst motiverade pilgrimer företar sin vallfärd i sällskap av kulturellt och historiskt intresserade vandrare, andra som beskriver sig som naturälskare intresserade av äventyret och den fysiska utmaningen, liksom pilgrimer med varierande individuella andliga motiv. Det är vanligt förekommande bland nutida pilgrimer att vandringen företas i samband med någon form av kris eller vägskäl i livet, såsom förlust av en nära anhörig, jobb- eller kärleksproblem, utbrändhet eller annan sjukdom. Vägen till Santiago, som bland pilgrimerna kallas rätt och slätt el Camino(Vägen) associeras också med skilda slag av alternativ andlighet eller new-age läror: några är intresserade av vägens förbindelse med Galiciens gamla keltiska kultur och religion, andra av berättelser om medeltida riddarordnar och mystiska tecken i arkitektur och landmärken, åter andra söker särskilda energier som antas utgå från vägen eller den speciella kraft som härrör från vägens form av en spegelbild av Vintergatan. Vägen till Santiago har till och med ett alternativt mål, som för många pilgrimer är Caminons riktiga slut. Det är Fisterra, klippformationerna där den spanska kusten möter Atlanthavet, en plats som på medeltiden troddes vara världens ände och associeras bland annat med de galiciska kelternas solriter.

Den stora variationen av trosföreställningar, motiv och nationaliteter i Santiagovallfärden ger vid handen att religionens återkomst i den här formen utmanar traditionella definitioner av religion på olika sätt. Man skulle kunna dra slutsatsen att Santiagovallfärden exemplifierar den pågå- ende trend som har setts som karakteristisk för religion i västerlandet idag: en individuellt utformad andlighet mer eller mindre oberoende av religiösa institutioner (Heelas $\&$ Woodhead 2005). Katolska kyrkan är inte omedveten om Camino-kulturens heterogenitet, tvärtom. Den för en noggrann statistik över pilgrimernas antal, nationalitet, ålder, kön och motiv för resan. Ett villkor för att få den så kallade Compostelan, ett intyg med pilgrimens namn i latin, är att motivet för resan har någon anknytning till religion eller andlighet. Kyrkan är generös i sin definition av vem som är en äkta pilgrim. Religiösa, allmänt andliga motiv blandade med kulturella räknas och precis som mässan är öppen för alla pilgrimer utfärdas intyget till den största delen av den brokiga skara som kommer till pilgrimskontoret i Santiago. Bara den som fyller i kolumnen "ej religiös» kan inte få intyget, utan ett annat mindre intyg utfärdas.

Statistiken som katolska kyrkan för ger en intressant bild av pilgrimskulturen, där blandningen av religiösa, andliga och "andra" motiv är den tydligaste trenden. För att tolka den närmare krävs dock en mer ingående kännedom om pilgrimernas egen tolkning av begreppen. Begrepp som "andlighet" och "religion" har inte någon avgränsad, entydig betydelse $i$ en postmodern kontext varken inom forskningen eller för religiösa/andliga utövare, än mindre i en mångkulturell pilgrimskultur. ${ }^{4}$

4 Begreppet "andlighet» är särskilt suddigt i kanterna. Zinnbauer et al. (2001) refererar till begreppet som "fuzzy». I en undersökning fann de betydande variationer mellan olika sociala gruppers användande av termen. 
Förutom motivets art sätter kyrkan ytterligare ett villkor för Compostelan: pilgrimen måste ha vandrat de sista ett hundra kilometerna av vägen, eller cyklat tvåhundra. Kyrkans villkor för att utfärda det officiella intyget anger vad den ser som definitionen av en äkta pilgrim: ett motiv som innefattar någon religiös eller andlig aspekt och ett mått av fysisk ansträngning som ska ha utförts genom det egna sättet att färdas.

\section{Santiago i Sverige}

Katolska kyrkans statistik förs över de pilgrimer som kommer till pilgrimskontoret och får ett utfärdat intyg. Det anger inte det totala antalet pilgrimer som färdas längs leden eftersom inte alla besöker pilgrimskontoret. Många vandrar leden i olika etapper, eller vandrar kortare sträckor och tar bussen ibland utan att särskilt ge akt på pilgrimskontorets villkor för intyg. Det verkliga antalet är därför troligen betydligt högre (men inte lägre). Enligt statistiken är spanjorerna fortfarande i majoritet, men den internationella andelen, där fransmän, italienare och tyskar dominerar, har vuxit. Pilgrimer från de nordiska länderna utgör ännu så länge en liten del av det totala antalet besökare på pilgrimskontoret, men antalet växer sedan början på 2000-talet. På pilgrimskontoret sommaren 2008 hade den ökade närvaron av svenska pilgrimer noterats av funktionärerna. Den bekräftas i statistiken: av 125.000 pilgrimer totalt var drygt 900 svenskar under 2008. Antalet svenska pilgrimer hade därmed mer än fördubblats sedan 2006. ${ }^{5}$

I Sverige finns (ännu) inte någon vänförening inom ramen för Santiago-vallfärdens organisation, som det gör i många andra länder. I Spanien fungerar vänföreningarna liknande den modell för religiösa brödraskap som är vanlig i katolska länder. De utgör en kontaktpunkt för pilgrimer på det lokala planet och deltar också i arbetet med leden, till exempel genom att driva ett härbärge vid leden. Vänföreningar finns i flera europeiska länder, bland annat Norge, och fungerar då som kontaktpunkt och informationscentral. I Sverige finns privata hemsidor som spelar en liknande roll, genom att publicera tips och råd om utrustning och färdvägar, berättelser om vandringar och chat-forum där man kan söka en vandringspartner. Svenska Kyrkans Pilgrimscentrum i Vadstena utgör också ett slag av kontaktpunkt för intresse för pilgrimsresande även om de inte har ett särskilt fokus på Santiago de Compostela, utan på pilgrimsvandring i Sverige. På Pilgrimscentrums hemsida utbyter pilgrimer råd och tips även om Santiago-vallfärden. Internet är överhuvudtaget de moderna pilgrimernas kommunikationsform och informationskälla, och svenska pilgrimer behöver givetvis inte begränsa sig till svenska hemsidor. Pilgrimskontoret i Santiago har en egen hemsida med utförlig information på de stora europeiska språken. ${ }^{6}$

I medier och bokproduktion tycks det svenska intresset för Santiago de Com-

5 http://archicompostela.org

6 http://archicompostela.org 
postela befinna sig i en »boom». Mängden av texter om Santiago de Compostela är överväldigande. Guideböcker, fotoböcker, skildringar i dagstidningarnas resebilagor och i veckotidningarnas reportage, texter på internet och det slag av texter som jag kommer att diskutera här: skildringar av vandringen i litterär form. Jag tar här upp en essä av Ulrika Kärnborg (2003) och två romaner av Anders Paulrud (2005) respektive Agneta Sjödin (2006). De svenska författarna är inte ensamma om att gestalta vandringen till Santiago i litterär form. Böcker av den brasilianske författaren Paolo Coelho, den amerikanska skådespelerskan Shirley MacLaine och den tyske komikern och författaren Hape Kerkeling är några av de mest kända som bidragit till det återuppväckta intresset för den gamla pilgrimsleden.

Publiceringen av de svenska böckerna sammanfaller med ökningen av antalet svenska pilgrimer till Santiago de Compostela. Jag betraktar böckerna som en del av resandekulturen kring Santiago. I min diskussion länkar jag dem dels till de existerande pilgrimspraktikerna och föreställningarna om Caminon, dels till en svensk kontext. Böckerna kan både ses som enskilda pilgrimers kulturella representationer av vandringens betydelse, men också som delar i den pågående konstruktionen av Santiago de Compostela där de blir ett bidrag från svensk horisont. Innan jag inleder diskussionen av de svenska författarnas skildringar ska jag placera in min diskussion i ett teoretiskt synsätt på sambanden mellan turism och pilgrimsresor och mellan resande och skrivande.

\section{Några teoretiska utgångspunkter}

Det ökade pilgrimsresandet i världen kan ses som en aspekt av ett ökat resande överhuvudtaget, snabbare och billigare transportmedel gynnar pilgrimsresande och den expanderande turistnäringen svarar i allt högre grad mot efterfrågan på resor till religiösa resmål. Santiago de Compostela är ett talande exempel på hur en stad aktivt använt sitt historiska och kulturella kapital för att bygga upp en blomstrande turistnäring, bland annat genom den lyckosamma kampanjen för att bli europeisk kulturhuvudstad år 2000 (Roseman 2004). De svenska vallfärderna till Santiago är inplacerade både i resenäringens och i pilgrimsledens infrastruktur; flyg- och tågresa Sverige - Spanien tur och retur för att möjliggöra vandring längs pilgrimsleden och övernattning i härbärgen som underhålls av den spanska staten, frivilligorganisationer och katolska kyrkan. Vid ankomsten till Santiago förvandlas pilgrimerna till turister då de efter utfärdat intyg och katedralbesök ger sig ut i staden, besöker dess många caféer och restauranger och kanske unnar sig ett bättre hotell efter de många nätterna i härbärgenas sovsalar. Variationen i motiv bland pilgrimerna till Santiago bidrar i sig till att lösa upp den dikotomiska distinktionen mellan den sekulära, njutningssökande turisten och den fromme, asketiske pilgrimen.

I den teoretiska diskussionen om pilgrimsfärder har ett flertal antropologer betonat att kategorierna resande, turism och pilgrimsfärder bör ses som besläktade och sammanbundna kulturella processer. 
Genom att se likheterna och kontinuiteten mellan pilgrimsresande och andra kategorier av resande och turism kan analysen av dem berikas (Badone \& Roseman 2004, Coleman \& Eade 2004). Ett sådant synsätt är i hög grad relevant för studiet av det samtida pilgrimsresandet till Compostela, som inom en och samma kulturella form härbärgerar religiösa, andliga och sekulära element.

I forskning om reseberättelser har det påpekats att resandepraktiker är sammanflätade med läsandets och skrivandets praktiker i det europeiska resandets historia (Gregory 1999). Reseskildrarens dagbok är redan medierad av tidigare resenärers berättelser, och hans eller hennes text kommer att ge upphov till nya resor och nya berättelser $\mathrm{i}$ en cirkulär rörelse utan slut. Berättelser om pilgrimsresor kan ses som en form av reseberättande med en lång tradition inom kristendomen. Pilgrimsresor har sedan tidig kristendom åtföljts av skrivande om resorna, under vissa perioder har pilgrimsresandet till och med skett endast i form av skrivande (Coleman \& Elsner 2003). Uppkomsten av vallfärdsorter i den kristna traditionen är ofta knutet till en berättelse om mirakler som skett på just den platsen, en berättelse som blir transformerad till text, sprids och blir början till konstruktionen av platsen som ett pilgrimsmål (Dubisch 1995, Gemzöe 2005). Till den ursprungliga berättelsen läggs sedan pilgrimers berättelser om nya mirakler, som i sin tur sprids och lockar fler pilgrimer till platsen. Pilgrimernas upplevelser på platsen är medierade av texter och muntliga berättelser på samma sätt som den sekuläre resenären ingår i en cir- kularitet mellan resande och berättande. Coleman och Elsner (2003) menar att pilgrimers praktiker i den kristna traditionen måste ses i förhållande till text: antingen så finner pilgrimer vad texterna har förberett dem på eller så konstruerar de en antistruktur som finner motsatsen till den textuella representationen av pilgrimsfärden. Petsalis-Diomidis (2003) visar i en studie av tre pilgrimstexter skrivna i skilda kulturella kontexter och sekler att författarna alla relaterar till en bild av en idealtypisk pilgrim, en idé om hur en pilgrimsresa bör utföras och upplevas, gentemot vilken de utvecklar betydelsen av sin egen resa. I de tre samtida svenska texter jag diskuterar här spelar en sådan idealtypisk pilgrim en central roll för berättelserna.

På samma sätt som den moderne resenären till Santiago kan ses om en hybrid mellan turist och pilgrim, så lånar de texter jag diskuterar här drag både från en europeisk tradition av reseskildringar och från religiösa texter om pilgrimsfärder. En cirkulär process mellan läsande, skrivande och resande kan ses som en del av mekanismerna i den återuppväckta vallfärden till Santiago. ${ }^{7}$ De tre författarnas texter ingår även de i en cirkularitet. Kärnborg, Paulrud och Sjödin har läst andra författare, historiska och samtida, innan de själva vandrade och deras böcker är sammanbundna i $i e n$ ordens gemenskap» (Coleman \& Elsner 2003 s. 9).

Ytterligare en teoretisk infallsvinkel är relevant $\mathrm{i}$ tolkningen av de tre författarnas texter. I den antropologiska forskningen

7 I mitt fältarbete studerar jag bland annat pilgrimers läs- och skrivpraktiker inom resandekulturen. 
om pilgrimsresande är Victor och Edith Turners tolkningsmodell av pilgrimsresan som en passagerit, trots de många efterföljande tolkningsmodellerna, fortsatt inflytelserik (Turner 1974, Turner \& Turner 1978). Med utgångspunkt i den franske folkloristen Arnold van Genneps teori om passageriter i förmoderna samhällen utvecklade Victor Turner begreppen liminalitet och communitas. Termen "liminal", från latinets limen som betyder tröskel, beskriver det tillstånd där individen befinner sig, i passagen mellan två sociala positioner, på tröskeln mellan två sociala världar. En viktig aspekt av tillståndet av liminalitet är dess kapacitet att generera communitas, ett tillstånd av djup gemenskap, kommunikation och jämlikhet mellan individer (Turner 1969, Turner \& Turner 1978). Turner och Turner föreslog att pilgrimsresor ersätter passageriter i moderna samhällen som symboliska rum för liminalitet och communitas. ${ }^{8}$ Idag avvisas den här teorin som en generell tolkningsmodell till förmån för en mer flexibel syn där begreppen kan belysa aspekter av vissa pilgrimsresor, men vara frånvarande i andra. (Eade \& Sallnow 1991, Coleman \& Elsner 1995, Dubisch 1995). I min tolkning av de svenska berättelserna om vandringar till

8 Genom resan till avlägsna heliga platser separeras pilgrimen från vardagslivets struktur, både geografiskt och socialt. På pilgrimsplatser som ofta befinner sig på geografiskt perifera platser, skilda från samhällenas politiska och ekonomiska centrum, kan pilgrimer erfara en direkt kontakt med helighet och ett tillstånd av communitas med andra pilgrimer (Turner \& Turner 1978).
Compostela använder jag begreppen liminalitet och communitas på det sättet.

\section{Förlorad religion}

I min analys av de tre texterna utgår jag från ett antal frågor: Vilken roll spelar "religion« och "andlighet» i texterna? Vilka element av pilgrimskulturen använder sig författaren av? Vilka bilder av en idealtypisk pilgrim återfinns i texterna?

Både i forskning om turism och forskning om reseberättande har det framhållits att det västerländska resandet ofta bär på en idé om att något som det materialistiska västerlandet har förlorat kan återfinnas på resor i främmande länder (Badone 2004, Duncan \& Gregory 1999). ${ }^{9}$ En sådan idé har främst setts som central i turism/reseberättande till icke-västerländska resmål, men återfinns också i exempelvis reseberättande där resenären kommer från en europeisk metropol och reser till landsbygden (se Sharpe 1999).

Den här idén återfinns i Ulrika Kärnborgs essä Stjärnfältet (2003), där huvudtemat är det moderna samhällets förlust av religion. I essäns form undersöker författaren fenomenet pilgrimsresande som en väg in i religionens värld med hjälp av andras texter om pilgrimsfärder och egna resor.

9 Taylor (2001 s.10) beskriver turism till ickevästerländska resmål och dess konstruktion av "de andraw: "They' become the lost sacredness of Western culture, they become its Other, and they are ascribed a spiritual and physical authenticity which the 'material' West has somehow lost". 
Kärnborg beskriver sitt motiv för pilgrimsvandringen som inte helt klart för henne själv, men relaterat till ett slag av inre kris. Hon hade kommit till en punkt i sitt liv då hon börjat känna att hon "levde i lögn" (s. 16). Den växande känslan av falskhet i hennes liv väckte behovet att få till stånd en förändring. Hon vände sig till pilgrimsritualen just på grund av dess potential som förnyelseritual: den skulle »kunna fungera som ett reningsbad" [ ... ] »ett sätt att börja om, ungefär som när man kastar något man skrivit, något som var illa tänkt och komponerat, i papperskorgen och tar fram ett nytt ark" (s.16). Men pilgrimsfärder tillhör religionens sfär, en sfär som är okänd för Kärnborg. Hon beskriver sig själv som en person utan någon tidigare relation till religion, som dotter till ateister är hon varken döpt eller konfirmerad. Innan hon påbörjade läsningen, resorna och skrivandet om vallfärder levde hon med föreställningen att resten av världens befolkning levde just som svenskarna: "lyckligt sekulariserade» (s.13). Under hennes arbete med boken hände det ofta att folk frågade henne varför hon blivit så intresserad av religion. Hon svarade med en motfråga: Hur kommer det sig att så många svenskar inte är det?

Varför framstod då pilgrimsvandringen till Compostela som det rätta sättet att närma sig religionen snarare än att börja gå i kyrkan på söndagarna hemma i Stockholm? Därför att den lutheranska kyrkan också har blivit sekulariserad och därmed inte förmögen att erbjuda vägar till inre frid. Sådana vägar kunde religionen erbjuda på medeltiden och de är också kända för människor i andra kulturer. Därför riktar
Kärnborg blicken mot det förflutna, till medeltiden och den gamla pilgrimsleden till Santiago.

Vägen till Santiago som en väg till att erfara något av den medeltida människans förhållningssätt till religion som lockar Kärnborg är ett centralt tema i det nutida vallfärdandet till Santiago, utarbetat i de flesta moderna guideböcker och fångat $\mathrm{i}$ den symbol som används för allt som har med Caminon att göra, en stiliserad vandrande man, med stav i handen (exempelvis Rudolp 2004, Bravo Lozano 1993). När återupplevandet av den medeltida pilgrimsleden startade i Spanien på 1950- och 1960- talen var det knutet till ett intresse för bevarandet av ett spanskt kulturarv. Med det ökade internationella intresset blev betoningen av leden som ett gemensamt europeiskt kulturarv viktig (Roseman 2004). I Kärnborgs text utgör Heliga Birgittas texter om sina resor till Santiago på medeltiden en länk mellan Sverige och katolsk kultur, och gör därmed det förflutna som Kärnborg söker mindre främmande. Det blir en del av ett gemensamt kulturarv, tillgängligt också för sekulariserade protestanter från norr.

I Kärnborgs text är Caminon en liminal plats, belägen i ett avlägset hörn av Europa, och framförallt utryckt ur tiden, placerad i det förflutna. Så fort Kärnborg anländer med sin man till St. Jean Pied-de-Port där den franska leden börjar har hon inträtt i den medeltida religionens värld, där hon fascinerad betraktar de andra pilgrimerna. Hon beskriver målande fransmännen, tyskarna och holländarna som »irrade omkring bland de låga, medeltida husen som vilsna 
skator" klädda i "underliga huvudbonader, slokhattar och illa tilltygade mössor» (s.18). Några bad med "smått extatiska miner som om de när som helst skulle kunna utbrista i hymner, laudi, som medeltidens botgörare" (s.18). Pilgrimerna var "en sort vi aldrig sett förut, moderna flagellanter, europeiska ruggugglor som hade kastat all rationalitet överbord...»(s.19).

Kärnborgs text uttrycker här den sekulariserade intellektuelles ståndpunkt: vallfärder och tro på mirakler är i grunden intellektuellt oförståeligt och till och med löjligt, medeltidens irrationalitet och vidskepelse som vetenskapen och upplysningen lämnat bakom sig. Men samtidigt är det denna så kulturellt främmande irrationella tro hon vill förstå. Som så många pilgrimer före henne vill hon uppleva ett sant mirakel. I Caminons liminala tillstånd är det möjligt: redan den första dagen i Pyrenéerna erfar hon religion på ett för henne ditintills okänt sätt.

På den första dagens vandring tar Kärnborg och hennes man av misstag en svårare väg över bergen. De hamnar i en snöstorm i Pyrenéerna och går vilse. När de frysande och genomblöta i tunna sommarkläder vandrat i flera timmar säger hennes man att "man kan frysa ihjäl på det här viset, jag tror att det kanske är farligt, vet du om vi har gått vilse?" (s. 23). I ett kritiskt ögonblick då Kärnborg ramlat omkull i snösörjan och säger att hon inte orkar längre, säger hennes man att det måste hon och morrar "be till Sankt Jakob». Kärnborg som inser den verkliga faran i deras situation gör just detta. Hon känner då som om en "vänlig men bestämd hand" knuffade henne framåt och snart hittar de tillbaka till civilisationen i form av ett härbärge (s. 23).

Från Freys (1998) studie av det moderna vallfärdandet till Santiago vet vi att det här slaget av upplevelse inte är ovanlig bland nutida pilgrimer. En sådan upplevelse kommer emellertid att få en annan betydelse för pilgrimer med katolsk uppfostran än för en svensk kvinna utan tidigare kontakt med religion. Kärnborg relaterar inte sin upplevelse till de andra pilgrimerna och beskriver inte sin egen resa som del av den samtida pilgrimskulturen. I hennes text är handlingen att be till Sankt Jakob en handling som visar hennes beredvillighet att öppna sig för det främmande, obekanta som "religiös erfarenhet« representerar för henne. Den visar att hon är uppriktig i sin ambition att nå bortom den intellektuella (o)förståelsen av religion för att istället själv uppleva. Efter episoden i bergen skriver Kärnborg att hon "faktiskt [föll] på knä och tackade Sankt Jakob« (s. 24).

Caminons liminalitet genererar således en direkt kontakt med den heliga, osynliga eller övernaturliga ordningen (Turner \& Turner 1978) men tillståndet av communitas förverkligas inte för Kärnborg. Det är just bilden av Caminon som en plats $i$ förfluten tid som skapar en klyfta mellan henne och de andra pilgrimerna. Det är den medeltida religiöse pilgrimen som är idealtyp i Kärnborgs text, men hon är förhindrad att identifiera sig fullt ut med denne och därmed också med de andra pilgrimerna på vägen. De andra pilgrimerna är bärare av det förflutna, de står närmre den idealtypiske medeltida pilgrimen än vad hon själv gör. Det skapar

Lena Gemzöe: Att skriva vägen till Santiago. 
en ambivalens i Stjärnfältet: hon avundas andra pilgrimer deras tro - det glömda och förlorade som hon söker på vägen till Santiago, men samtidigt förblir "de andra" låsta $\mathrm{i}$ ett förrationellt förflutet. I en prolog beskriver Kärnborg mötet med två spanjorer, en far och en son. De ska vandra den långa vägen till Santiago och be till St Jakob om bot för sonen som har ett funktionshinder. Kärnborg känner sig olustig i deras sällskap och frågar dem skeptiskt: "Så ni är riktiga pilgrimer?». Hon jämför deras nötta kläder och utgångna tunna skor med sina och hennes mans moderna utrustning. De gör ett tröstlöst intryck på henne, men när de skiljs åt "var det de som betraktade oss med medlidande och inte tvärtom" (s. 8). Här blir "de andra" representanter för något som den moderna människan förlorat. Berättelsen kan fogas in i en lång tradition av europeiskt reseberättande där resenären från en utkikspunkt i ett europeiskt, urbant centrum på andra platser - andra kontinenter eller landsbygden inom Europa - ser hos den religiöse/ kulturelle andre ett mindre modernt och fattigare tillstånd i mänsklig kultur, men som ändå äger något som det moderna samhället har förlorat (Gregory 1999, Sharpe 1999).

På Caminon möter Kärnborg således "riktiga pilgrimer" av det slag hon inte visste existerade. Såväl de fattiga, spanska katolikerna som, likt miljoner andra katoliker världen över, genomför pilgrimsresan för att bli helade från sjukdom, som de internationella pilgrimer hon möter i St. Jean Pied-de-Port, de "moderna flagellanterna", är av ett annat slag än hon själv. Men många av dessa har kommit till
Caminon av liknande skäl som hon själv och kanske upplevt att Sankt Jakob givit dem en knuff framåt. Vad är det då för skillnad?

När Kärnborg beskriver sig själv i möten med andra pilgrimer och med den katolska kulturen är det inte utan ironi, en blick på det komiska i situationerna. Vad hon försöker beskriva i dessa passager är just känslan av att inte vara en "riktig" pilgrim. Efter att ha upplevt miraklet i snöstormen känner hon sig öppen för religionens värld och deltar i en katolsk mässa. Där tar hon också för första gången i sitt liv nattvarden. Samtidigt skäms hon för att hon saknar gudstro när den främmande prästen lägger oblaten på hennes tunga. Kärnborgs känsla av att inte vara en autentisk pilgrim, trots nattvard och bön till helgon, berör den flytande skiljelinjen mellan turisten och pilgrimen. Kärnborg upplever att hennes eget deltagande i Caminons riter liknar turistens. Hennes upplevelser liknar de erfarenheter som turister söker när de tar del mer aktivt $i$ kulturen på de platser de besöker - att prova en främmande kulturs mat, klä sig i lokala klädesplagg, lära sig en dans, eller i det här fallet, en ritual. Kärnborgs närmande till Santiago-vallfärden uppvisar en sådan villighet att "pröva" katolicismens ritualer. Liksom turisten på solresa för en tid blir ett annat jag, vackrare och kanske mer sensuell, kan Caminon erbjuda en upplevelse av att under en tid få tillgång till ett religiöst jag. Kärnborg upplever det icke-autentiska i situationen, men kan sägas tillhöra det ökande antal pilgrimer som närmar sig traditionella pilgrimsmål på ett postmodernt sätt 
som innefattar lekfullhet, nyfikenhet, en prövande hållning (jfr. Coleman 2004). ${ }^{10}$

\section{Kärlek vid världens ände}

Det intellektuella utforskandet av pilgrimsresande som en väg till att förstå innebörden av förlusten av religion är huvudtemat i Stjärnfältet, medan författarens självbiografiska, subjektiva upplevelse av pilgrimsresande är underordnad till huvudtemat. I Anders Paulruds roman Kärleken till Sofia Karlsson är huvudtemat, och berättarjagets motiv för att ge sig ut på en vandring till Santiago, förlust av kärlek. Vid sidan av detta huvudtema vävs reflektioner om Gud och religion in i berättelsen.

Medan Kärnborgs upplevelser på Caminon centreras till Sankt Jakob och pilgrimsresan som medeltida helgonkult, använder Paulrud ett annat rituellt element som Camino-kulturen erbjuder. När berättarjaget, vars namn liksom författarens är Anders, påbörjar sin resa är han svag av sjukdom och kärlekssorg. Han är nu botad från den cancer som drabbade honom, men övergiven av sin älskade. Den jagets kris han upplever vill han lösa genom att gå till "världens ände». Världens ände är målet för hans vandring där hans älskade gömmer sig och han kommer att återförenas med henne. Paulrud använder på det sättet den symboliska kraften i platsen Fisterra,

10 Coleman (2004) beskriver den postmoderna inställning som en del pilgrimer till Walsingham, "Englands Nazareth" har då de förhåller sig lekfullt till ritualerna och platsen som besöks över en weekend.
Caminons alternativa icke-kristna mål, för att skapa en plats utanför tid och rum i sin berättelse. Platsen är liminal i bokstavlig betydelse, med Turner's ord "representerar den en tröskel, en plats och ett ögonblick 'i och utanför tiden' (1974 s.197, min övers.). Den passagerit som pilgrimsfärden erbjuder honom är att gå till den liminala platsen, återfinna den kärlek han förlorat och återvända förnyad och helad från den smärta som övergivandet har åsamkat honom.

Under vandringen reflekterar berättarjaget över Gud och kristendomen. Liksom Kärnborg hänvisar Paulrud till medeltida källor, Heliga Birgittas texter och Picauds pilgrimsguide från 1100-talet. Men om Kärnborg undrar varför svenskar, som representerar moderniteten $\mathrm{i}$ hennes berättelse, har förkastat religion, är Paulruds berättarjag en kritisk röst gentemot kyrkan. Han saknar vad religionen skulle ha kunnat erbjuda om kyrkan inte hade förstört religion och gjort det omöjligt att tro. När berättarjaget mest behövde Gud, när han var sjuk och senare övergiven av sin älskade, fanns Gud inte där. Han beskriver operationen då hjärntumören togs bort: "De där gåtfulla sekunderna på båren i operationssalen $i$ ögonblicket innan jag somnade: grönt tyg, munskydd, gula kakelplattor. Inte ens då visade han sig, Gud» (s. 56).

Hans vandring på Caminon är en vandring i total ensamhet - »Men jag är ensam. Förblir ensam" (s. 56), inte bara övergiven av sin älskade utan också av Gud. Han har dock i sin ensamhet en följeslagare, någon som kan ge honom råd. Det är en varelse han kallar ängeln. Ängeln är som han själv man, medelålders, lite trött, ibland lat. Han 
dyker upp då och då, men inte alltid, och ger råd till berättaren. Han anstränger sig att övertyga läsaren om att ängeln inte ska ses som en av Guds änglar. Den är snarare som den tyske poeten Rilkes ängel: »en budbärare, en transportör som kommer med råd och anvisningar, en som föreslår utvägar och alternativ till ett annat andligt liv än nödvändigtvis det kristna» (s. 67). Hans egen ängel »verkar inte tro på en enda Gud» utan »opererar ensam som en luggsliten och cynisk deckare» (s. 67).

Religion, i form av kristendomen, är närvarande i Paulruds bok genom förkastandet av kyrkans religion. Samtidigt skapar författaren en varelse som tycks spela en roll liknande den som personliga skyddshelgon har för katoliker. I sitt resonemang om änglar skriver han att "i ett korrekt kristet sammanhang" fungerar ängeln som en kontaktperson mellan Gud och människa (s. 67). På det här sättet skapar han ett religiöst/ rituellt universum för sig själv som existerar inom Caminons liminalitet, ett universum där det religionen skulle kunnat vara är tillgängligt. Som en parallell till de uttalade tankarna om Gud beskrivs den inre krisen delvis i ett religiöst språk, särskilt i gestaltningen av övergivenheten. Han talar om kärleken som nåd, en nåd Sofia, den älskade kvinnan, givit honom. Han längtar efter försoning och en ny nåd som han ska finna vid världens ände. Kärlekslängtan och gudslängtan smälter samman i Paulruds berättelse. Hans ängel ger sig ibland tillkänna som »en längtan efter evig kärlek» (s. 67).

Målet för Anders vandring är alltså inte katedralen eller pilgrimskontoret där intyg utfärdas och berättelsen nämner ingen av de kyrkliga ritualerna. Berättarjaget tillbringar en natt i Compostela och tar sedan bussen vidare till Fisterra och där utför han en ritual som sätter punkt för den del av berättelsen där hans mål är att finna den älskade. "När jag äntligen kom fram till världens ände var hon inte där« (s. 125) skriver han och skapar sedan en egen ritual. Han ställer sig på klipporna och kastar en sten i oceanen, en sten som för honom och Sofia symboliserade bandet dem emellan och som han burit med sig hela vägen. Ritualen beskrivs som hans personliga, men med sin sten i oceanen sällar sig Anders till de moderna pilgrimernas alternativa ritualer vid Caminons slut där efterlämnade klädesplagg, skor och andra föremål ligger instuckna i klippskrevorna som de materiella manifestationerna av pilgrimers kvarlämnade förflutna. Ritualen med stenen vid världens ände markerar Anders försoning med att Sofia övergivit honom, som senare i berättelsen leder till en försoning också med ett tidigare smärtsamt minne av övergivande, då han som litet barn blev bortadopterad av sin mor.

Paulruds berättelse knyter an både till Caminons kristna symbolik och till dess kraft som liminalitet. Dessa teman anslås på bokens första rader: "Jag börjar här. En dag kom en ängel ner till mig med bud. 'Hon är vid världens ände', sa han innan han svävade upp igen«. Det är dock symboliken som härrör ur Caminons liminalitet i tid och rum som är central i berättelsen. Caminon som periferi och "hemma» som centrum är uttalat i avsnittet där Anders lämnat världens ände och återvänder hem till "det som skulle ha varit mitt centrum, den efterlängtade värmen i mittpunkten» 
(s. 131). Vandringen till den geografiskt liminala platsen "världens ände« är också en vandring till dåtiden, den egna dåtiden: "Jag går vidare, går framåt men samtidigt bakåt, in i min egen dåtid» (s. 106). Och när berättarjaget nått världens ände börjar vägen till framtiden. Berättelsen slutar, efter försoning med övergivandena, med orden "Nu börjar framtiden".

Inte heller Paulruds berättarjag upplever något som kan liknas vid communitas på sin vandring. Han har inga relationer med andra pilgrimer, han vandrar ensam. Liksom Kärnborg funderar Anders, men kanske mindre bekymrat, över om han är en riktig pilgrim. "Jag är fortfarande ingen riktig pilgrim, jag har ingen djävla Gud över mig, men en botvandring är det. Något invärtes« (s.15). Han skiljer sig från de religiösa pilgrimerna, men också från några av de moderna. Anders fnyser åt "fuskpilgrimer" han stöter på: "på mountainbikes, med sina cykelhjälmar och färgglada kläder i nylon. De borde förbjudas" (s. 110). Paulrud konstruerar i sin text en idealtypisk pilgrim som inte nödvändigtvis är religiös, men inte heller som cyklisterna som antas sakna ett "invärtesu förhållande till vandringen. Paulruds idealtypiske pilgrim ligger därmed nära den nutida Camino-kulturens, och katolska kyrkans: inte bara den fysiska ansträngningen räknas, utan någon form av inre "resa» definierar en riktig pilgrim på vägen till Santiago de Compostela.

\section{I mästarens fotspår}

Agneta Sjödins En kvinnas resa är en roman som handlar om en ung kvinna,
Maria, som genomför en vandring till Santiago de Compostela.

I En kvinnas resa möter Maria en berömd författare som hon beundrar oerhört. Han kallas Mästaren. Maria lider av dåligt självförtroende och misslyckat kärleksliv och vet inte vad hon ska göra med sitt liv. Hon vänder sig till Mästaren och önskar få del av hans mystiska livsvisdom. Hon vill förstå det som Mästaren skrivit i en av sina böcker: "'Tecken är ett språk, ett språk vi utvecklar för att tala med världssjälen, universum, Gud eller vad du nu vill kalla det'« (s. 12). Mästaren säger att han kan lära henne att tyda tecken och ger henne rådet att vandra vägen till Santiago de Compostela. Med en stark längtan att uppleva det mystiska - "Mystiken bildade ett hav av möjligheter att dyka ner $i$, och Maria längtade ner i djupen" (s. 12) följer Maria Mästarens råd.

I Sjödins berättelse får vi följa Maria från förberedelserna hemma, den första dagens vandring över Pyrenéerna, mässan i klostret i Roncesvalles som hon deltar i likt Kärnborg, över de olika anhalterna fram till katedralen i Santiago. Under hela vandringen letar hon efter mystiska tecken, men finner inga vilket gör henne bedrövad. Paradoxalt nog är Sjödins roman den bok av de tre där frånvaron av mystiska händelser eller ritualer är mest påtaglig. Istället utvecklar sig berättelsen till en historia om de dagliga vandringarna, de pilgrimer hon möter och dess huvudtema: hur vandringen uppväcker minnen av tidigare traumatiska erfarenheter. Maria har blivit utsatt för både våldtäkt och fysisk och psykisk misshandel i tidigare relationer med män, upplevelser som hon skämts över och 
förträngt, men som hon under vandringen lyckas bearbeta och försonas med för att återvända hem som en starkare människa. Höjdpunkten i berättelsen och resan, som motsvarar Kärnborgs knäfall för Sankt Jakob och Paulruds sten-ritual vid världens ände, är den känsla av befrielse, triumf och styrka Maria erfar när hon kommit till den sista etappen av vandringen. Hon bestämmer sig för att gå de sextiofem sista kilometerna på en dag utan övernattning, en anmärkningsvärd fysisk bedrift som lyckas.

Varje kapitel i En kvinnas resa inleds med citat från Bibeln, filosofer eller författare, men Maria är inte upptagen av religiösa grubblerier. Den religiöse pilgrimen spelar därför inte rollen av en idealtyp som huvudkaraktären ställer i relation till sin egen vandring, på det sätt som sker i Kärnborgs och Paulruds böcker. Maria har en självklar gudstro: inför ett krucifix i katedralen i Léon upplever hon Jesu närvaro, vid Cruz de Ferro ber hon till Gud, i katedralen ber hon till Sankt Jakob och visar vördnad inför hans reliker. Men även i Sjödins bok brottas huvudkaraktären med en bild av en idealtypisk pilgrim som hon inte kan nå upp till, en bild som härrör från Mästarens manus där målet är att lära sig "tyda tecken". Att Maria inte finner några sådana gör henne besviken och får henne att känna sig »rätt värdelös» (s. 180).

Sjödins bok har tydliga intertextuella referenser till Paolo Coelhos Pilgrimsresan. I Coelhos bok förekommer en mästare som beledsagar huvudpersonen på vägen till Santiago och ger honom konkreta, andliga övningar att utföra, övningar som ska leda till initiering $i$ en riddarorden, som markeras med mottagandet av ett svärd. Maria vandrar leden på uppdrag av en Mästare, om vilken hon fantiserat att han är medlem $i$ en hemlig orden och att hon ska invigas i den när hon lärt sig tyda tecken. Vandringens sista dag och dess befriande upplevelse av styrka, beskrivs, inte i religiösa termer, utan som en upplevelse av att det "bodde en oövervinnerlig krigare inom henne som aldrig skulle tveka att dra sitt svärd och strida för ljuset» (s. 180). Och här vänder berättelsen, i den avslutande delen av boken avvisar hon Mästaren och hans mysticism, men hon har funnit sin egen styrka. Kan En kvinnas resa också läsas som feministisk befrielselitteratur, en historia om en kvinna som reser sig ur ett manligt förtryck? Maria helar sig själv från minnen av våldtäkt och misshandel, delvis med insikter som modern feminism har formulerat ("tänk om hon vetat det hon visste idag: att hon faktiskt hade rätt att säga nej, att det var hon som bestämde över sin kropp och sitt livu s. 92). Mästaren skulle kunna ses som en symbol för patriarkatet och Marias beroende av män, som hon frigör sig från. Det är en berättelse om en kvinnas väg till större oberoende och styrka, men den vägen har inte feministiska förtecken. De övergrepp Maria utsatts för eller Mästarens makt över henne sätts inte i samband med en övergripande manlig maktstruktur eller med andra kvinnors lika kuvade ställning. Det är genom att bli fri från dålig självkänsla och försonas med det hon utsatts för som Maria blir stark, betoningen ligger på terapeutiskt helande och individuell styrka, inte feministisk medvetenhet.

Sjödins bok skiljer sig från Kärnborgs och Paulruds texter på ytterligare en central punkt. Även om Caminon som mys- 
tiskt universum är del i Marias motiv att söka sig dit, så betonas inte Caminon som liminal och främmande i särskilt hög grad. Däremot är aspekter av det som brukar associeras med Turners begrepp communitas centrala i berättelsen. Sjödin skriver om enkelheten i livet på vägen och gemenskapen med andra pilgrimer i vandringen och på härbärgena. Även om hennes karaktär Maria vandrar ensamma delar av sträckan, så är ensamhet inte så framträdande som hos Kärnborg och Paulrud. Maria vandrar långa delar av sträckan tillsammans med två italienska män som blir hennes vänner. Hon upplever djup gemenskap med dem och hon sörjer att de av olika skäl inte kom att dela ögonblicket då de anlände till katedralen. Hos Sjödin beskrivs en central aspekt av Camino-kulturen: möten mellan pilgrimer med olika tro och olika nationaliteter som upplevs som en del av det som gör pilgrimsvandringen meningsfull. En sådan solidaritet mellan pilgrimer över kulturella och religiösa gränser, med drag av Turners tillstånd av communitas, har kommit att bli en del av de kulturella föreställningarna om Camino-kulturen och används aktivt i marknadsföringen av Caminon och Santiago de Compostela som turistmål (Roseman 2004).

\section{Pilgrimsvandring som återkomst av religion}

Om pilgrimskulturen längs vägen till Santiago de Compostela kan ses som en religionens återkomst, så ligger en del av dess dragningskraft i att den erbjuder en väg för att söka, undra och ställa frågor om Gud och religion som individ, utan att nödvändigtvis blanda in kyrkans institutioner och ritualer. Man kan undvika dem helt som Paulruds karaktär, pröva dem som Kärnborg eller umgås förtroligt med dem som Maria i Sjödins bok. Att vägen till Santiago är en väg för andliga sökare är nästan en truism, men det andliga sökandet kommer att se olika ut beroende av pilgrimernas olika tillhörighet i nationella, kulturella och religiösa kontexter. I Kärnborgs och Paulruds texter finns en tydlig gudslängtan, uttryckt som en känsla av förlust hos Kärnborg och som övergivenhet hos Paulrud. Båda relaterar till religion på ett individualiserat sätt, deras sökande är inte del av och leder inte till gemenskap med andra. Kärnborg beskriver i Stjärnfältet hur hon efter vandringen på Caminon deltar i en pilgrimsvandring i grupp på svensk mark, anordnad av Pilgrimscentrum i Vadstena. I ritualen ingår en övning där deltagarna förväntas dela sina erfarenheter med varandra genom att berätta om dem för gruppen. Kärnborg inser då att hon är oförmögen att "dela", gemenskapsritualen är främmande för henne. Paulruds karaktär söker inte heller gemenskap med andra, hans gudslängtan sammansmälter med hans längtan efter förening med en annan individ i tvåsam kärlek, en av det moderna samhällets få former av fullständig gemenskap.

Både Kärnborg och Paulrud vänder sig till pilgrimsvandringen främst som ritual och praktik. Caminons symboliska liminalitet erbjuder den upplevelse av religion som Kärnborg söker. Genom den geografiska och sociala separationen från vardagslivets struktur, på en helig plats skild från det egna samhällets politiska och ekonomiska 
centrum, erfar hon »en direkt kontakt med helighet» (Turner \& Turner 1978). Paulrud använder Caminon just så som Kärnborg karakteriserar det moderna samhällets förlust av religion, en förlust av sätt att hantera lidande och död. Caminon som liminal plats utanför tid och rum med dess alternativa pilgrimsritualer blir i Paulruds berättelse vägar till helande. I båda texterna fungerar tidigare texters religiöse pilgrim som en idealtyp gentemot vilken berättelsen tar spjärn.

I Sjödins berättelse återfinns den blandning av religiösa, andliga och sekulära inslag som karakteriserar Camino-kulturen med ett särskilt tilltal till kvinnor. Sjödins Maria sprider ett budskap som förenar kristen tro, en lätt dragning åt new agemysticism, egen-terapi och modern träningskultur. Det är ett budskap som också är starkt individualiserat, det är med egen kraft som individen kan helas. Samtidigt beskrivs i Sjödins berättelse en annan del av Caminons attraktionskraft: gemenskap med andra vandrare på vägen.

I de pilgrimsfärder i textuell form som diskuteras här är »återkomsten av religion" främst en återkomst, eller ett sökande av, en kroppsligt upplevd religiositet/andlighet. Det gäller för de tre berättelserna, men det är i Sjödins bok som vandringen som fysisk bedrift tydligast åstadkommer den själsliga förändringen av hennes huvudkaraktär. Genomförandet av den sista långa vandringsetappen ger Maria kontakt med en egen inre styrka som förändrar hennes liv. Den beskrivs inte främst i förhållande till tro eller andlighet, utan som en direkt upplevelse av den egna kroppens styrka, som också blir en mental kraft.
Den pilgrimsteoretiska diskussionen har påvisat på en mängd olika sätt hur pilgrimsresande inte kan ses som ett renodlat "religiöst « fenomen, det är alltid sammanflätat med andra kulturella praktiker och strömningar (Coleman 2002). De tre svenska berättelserna är sammantvinnade med en europeisk pilgrimskultur och strömningar i en svensk kontext på ett sätt som påvisar pilgrimskulturens elasticitet. Kärnborgs essä utvecklar teman som anknyter till ett pågående offentligt samtal om religionens återkomst i Sverige; hennes pilgrimsberättelse blir ett idiom för en konflikt mellan andlighet och intellektualitet som har en generell giltighet. År 2009 ledde föreningen Humanisternas kampanj för ett sekulärt samhälle till en debatt där kritiker menade att Humanisternas syn på religion var trångsynt och delvis etnocentrisk: religion, uppfattat som ett alltigenom negativt fenomen, sågs som något som tillhör "de andra", judar och muslimer, inte svenskar. Kritikerna, däribland författare, menade också att Humanisternas syn på religion som en antites till rationalitet och modernitet omöjliggjorde en diskussion mellan troende och icke-troende och att just författare borde visa förståelse för rikedomen i religiös kultur. ${ }^{11}$ Ambivalensen i Stjärnfältet speglar polerna i den här diskussionen och härrör från att Kärnborg intar båda förhållningssätten samtidigt: både den intellektuelles ståndpunkt som ser religion som irrationell, tillhörig kulturella »andra» utanför

11 Debatten startade i Dagens Nyheter 15/6 2009 med ett inlägg av Göran Rosenberg och pågår fortfarande (augusti 2009). Den kan följas på www.dn.se. 
det sekulariserade Sverige och en hållning som vill uppleva religionens helande kraft.

Sjödins bok och Marias fysiska bedrift på vägen till Santiago å andra sidan länkar in i en modern hälso- och motionskultur i Sverige. Månadstidningar med hälsa, psykologi och andlighet som tema tar upp pilgrimsvandring som en väg till kroppslig och själslig hälsa. Intresset för Sjödins bok är delvis en del av en sådan trend, samtidigt som hennes bok bidrar till trenden. Sommaren 2009 tycks intresset för boken nå en ny topp, då den förekommer i tre olika månadstidningar som vänder sig till främst kvinnliga läsare med intresse för hälsa, träning och egen utveckling. ${ }^{12}$ Ett sådant intresse kan vara en av förklaringarna till den vändning i Caminokulturens genusbalans som det svenska pilgrimsresandet utgör. Från att ha varit manligt dominerad under en lång tid har andelen kvinnliga pilgrimer gradvis ökat. Ökningen av det svenska pilgrimsresandet bidrar till den trenden - bland svenskarna var två tredjedelar kvinnor år 2008, medan män fortfarande var i majoritet bland det totala antalet pilgrimer. ${ }^{13}$

En kvinnas resa aktualiserar även den kontext som utgörs av bokbranschens lansering av författare och deras böcker. Sjödins bok är den av de tre böckerna som sålt mest

12 Tara, nr 11 2009, ToppHälsa nr 8 2009, Må Bra nr 82009

13 www.archicompostela.com, muntlig information Pilgrimskontoret, 2008. De genuskodade betydelserna i Camino-kulturen och variationer sammanhängande med genus, ålder och sexualitet bland pilgrimer är fokus i andra delar av den här studien, exempelvis Gemzöe 2009. och blivit mest uppmärksammad i medierna. Författaren själv spelar en viktig roll i marknadsföringen, dels genom sin redan tidigare etablerade mediala berömmelse, dels genom intervjuer och framträdande där författaren berättar om sin egen pilgrimsvandring. Caminons dragningskraft som symboliskt rum ingår här i en mäktig förening med den mediala berömmelsens magnetism. Bland de informanter jag intervjuat omtalas romankaraktären Maria och författaren Sjödin som samma person. I det här fallet förstärks cirkulariteten mellan berättande, läsande och resande genom författarens egen synlighet och berömmelse. Här finns också en parallell till författaren Paolo Coelho, som associeras till Caminon som en författare som vandrat leden. I båda fallen, men i olika samhälleliga kontexter, förstärks en kulturell konstruktion av Caminon som en väg där författare vandrar och skriver, en väg som kan vara en passagerit till författarskap. Därmed illustrerar den en annan aspekt av passagerit-modellens tillämpning på pilgrimsresande, som innebär att pilgrimen når en högre status efter genomförd resa (Turner \& Turner 1978). I reseberättarnas fall leder den personliga förändring de genomgår under resan till en högre status, författarens, en status med avsevärt socialt och kulturellt kapital i det moderna samhället.

De tre böckerna ingår således i vidare kulturella sammanhang och strömningar i tiden. Som framgår av ovanstående korta utblick, som inte på något sätt är uttömmande, så leder trådar från pilgrimskulturen till, sinsemellan mycket olika, kulturella sammanhang. Diversifieringen i Caminokulturen återspeglas $i$ de tre författarnas 
bilder av vägen till Santiago: böckernas pilgrimer delar ingen trosuppfattning och deras Camino tycks inte ha någon gemensam ritual, förutom vandringen, eller ens ett gemensamt slutmål. Sammantaget har de dock ett kraftfullt, gemensamt budskap: pilgrimsvandring som ritual, i sina oändligt varierade individuella utformningar, fungerar. Med sina berättelser har de tre författarna skapat nya idealtypiska pilgrimer, i vars fotsteg de inbjuder andra att vandra.

\section{Referenser}

Badone, Ellen (2004) „Crossing Boundaries: Exploring the Borderlands of Ethnography, Tourism and Pilgrimage». In Ellen Badone \& Sharon Roseman (eds.) Intersecting Journeys: The Anthropology of Pilgrimage and Tourism. Urbana \& Chicago: University of Illinois Press.

Badone, Ellen \& Roseman, Sharon (2004) "Approaches to the Anthropology of Pilgrimage and Tourism". In Ellen Badone \& Sharon Roseman (eds.) Intersecting Journeys: The Anthropology of Pilgrimage and Tourism. Urbana \& Chicago: University of Illinois Press.

Bravo Lozano, Millan (1993) A Practical Guide for Pilgrims. The Road to Santiago. León: Everest.

Coleman, Simon (2002) „Do You Believe in Pilgrimage? From Communitas to Contestation and Beyond". Anthropological Theory2, 3.

Coleman, Simon (2004) „Pilgrimage to 'England's Nazareth': Landscapes of Myth and Memory at Walsingham". In Ellen Badone \& Sharon Roseman (eds.) Intersecting Journeys: The Anthropology of Pilgrimage and Tourism. Urbana \& Chicago: University of Illinois Press.

Coleman, Simon \& Eade, John (eds.) (2004) Reframing Pilgrimage: Cultures in Motion. London: Routledge.

Coleman, Simon \& Elsner, John (eds.) (1995) Pilgrimage, Past and Present: Sacred Travel and Sacred Space in the World Religions. London: British Museum Press.

Coleman, Simon \& Elsner, John (eds.) (2003) Pil- grim Voices: Narrative and Authorship in Christian Pilgrimage. New York: Berghahn Books.

Duncan, James \& Gregory, Derek (1999) „Introduction". In James Duncan \& Derek Gregory (eds.) Writes of Passage: Reading Travel Writing. London: Routledge.

Dubisch, Jill (1995) In a Different Place: Pilgrimage, Gender, and Politics at a Greek Island Shrine. New Jersey: Princeton U. P.

Dubisch, Jill \& Winkelman, Michael (2005) Pilgrimage and Healing: Sacred Journeys. Arizona: Arizona University Press.

Eade, John \& Sallnow, Michael (eds.) (1991) Contesting the Sacred: The Anthropology of Pilgrimage. London: Routledge.

Egan, Keith (kommande) "I want to feel the Camino in my Legs': Trajectories of walking on the Camino de Santiago». In R. Blanes \& A. Fedele (eds.) Beyond Body and Soul: Anthropological Approaches to Corporeality in Contemporary Religion. New York: Berghahn.

Frey, Nancy (1998) Pilgrim Stories. On and Off the Road to Santiago - Modern Journeys Along an Ancient Way in Spain. Berkeley: University of California Press.

Gemzöe, Lena (2005) „The Feminisation of Healing in Pilgrimage to Fátima.» In Jill Dubisch \& Michael Winkelman (eds.) Pilgrimage and Healing: Sacred Journeys. Arizona: Arizona U.P.

Gemzöe, Lena (2009) The meanings of suffering on the road to Santiago. Gender, text and postsecularity among Swedish pilgrims. Paper pre- 
senterat på $7^{\text {th }}$ European Feminist Conference, Utrecht 4-7 juni.

Gregory, Derek (1999) „Scripting Egypt: Orientalism and the Cultures of Travel«. In James Duncan \& Derek Gregory (eds.) Writes of Passage: Reading Travel Writing. London: Routledge.

Heelas, Paul \& Woodhead, Linda (2005) The Spiritual Revolution: Why Religion is Giving Way to Spirituality. Oxford: Blackwell.

Kärnborg, Ulrika (2003) Stjärnfältet. En essä om helgon och skoskav. Stockholm: Bonnier.

McLeod, Hugh \& Ustorf, Werner (2005) The Decline of Christendom in Western Europe 1750-2000. Cambridge: C.U.P.

Paulrud, Anders (2005) Kärleken till Sofia Karlsson. Stockholm: Bonnier.

Petsalis-Diomidis, Alexia (2003) "Narratives of Transformation: Pilgrimage Patterns and Authorial Self-Presentation in Three Pilgrimage Texts». In Simon Coleman \& John Elsner (eds.) Pilgrim Voices: Narrative and Authorship in Christian Pilgrimage. New York: Berghahn Books.

Roseman, Sharon (2004) "Santiago de Compostela in the Year 2000: From Religious Center to European City of Culture». In Ellen Badone \& Sharon Roseman (eds.) Intersecting Journeys: The Anthropology of Pilgrimage and Tourism.
Urbana \& Chicago: University of Illinois Press. Rudolph, C. (2004) Pilgrimage to the End of the World. Chicago: University of Chicago Press.

Sharpe, Joanne (1999) "Writing over the Map of Provence. The touristic therapy of a Year in Provenceu. In James Duncan \& Derek Gregory (eds.) Writes of Passage: Reading Travel Writing. London: Routledge.

Sjödin, Agneta (2006) En kvinnas resa. Stockholm: Bazar förlag.

Taylor, John P. (2001) "Authenticity and Sincerity in Tourism". Annals of Tourism Research 28, pp. 7-26.

Turner, Victor (1969) The Ritual Process. Structure and Anti-Structure. Ithaca, N Y: Cornell University Press.

Turner, Victor (1974) „Pilgrimages as Social Processes». In Dramas, Fields and Metaphors: Symbolic Action in Human Society. Ithaca, N Y: Cornell University Press.

Turner, Victor \& Turner, Edith (eds.) (1978) Image and Pilgrimage in Christian Culture: Anthropological Perspectives. Oxford: Basil Blackwell.

Zinnbauer Brian J., Pargament Kenneth, Cole Brenda, Rye Mark S., Butter Eric M., Belavich Timothy G., Hipp Kathleen M., Scott Allie B. \& Kadar Jill L. (2001) "Religion and Spirituality: Unfuzzying the Fuzzy». Journal of the Scientific Study of Religion, pp. 549-564.

Lena Gemzöe: Att skriva vägen till Santiago. 


\section{Summary}

\section{Writing the road to Santiago}

The contemporary reanimation of pilgrimage to Santiago de Compostela seems to be a perfect illustration of what social scientists have labelled a re-emergence of religion. Each year, more than 100,000 pilgrims walk (some go by bike) the 800 kilometres along the road in northern Spain, and the number of pilgrims is increasing. However, the very heterogeneity of pilgrimage to Santiago in terms of the pilgrims' motives, nationalities, beliefs and ways of performing the pilgrimage makes it clear that this "re-emerging religion" defies any conventional definition of religion.

The number of Swedish pilgrims who undertake the journey is still small, but it has increased in the last decade. In this article I discuss the reanimation of the Santiago pilgrimage in Sweden, with a focus on one of its aspects: the publication of literary accounts of journeys to Santiago (an essay by Ulrika Kärnborg 2003, and novels by Anders Paulrud 2005 and Agneta Sjödin 2006).
It is argued that the Swedish narrators construct the road to Santiago as an imagined religious/ritual community, where one can ask questions about the nature of God and religion, without interference by the institution of the Church. Kärnborg seeks the religion that rational, modern society has lost, Paulrud's authorial self longs for what religion could have been if the Church had not destroyed it, whereas Sjödin's character wants to experience the New Ageinspired mysticism of the road to Santiago. The three narratives all include a personal journey, in which the elements of liminality and communitas that the pilgrimage experience offers are employed in varying ways.

Finally, I argue that a circular process between reading, writing and journeying, which has been seen as characteristic of European travelling practices in general and Christian pilgrimage in particular, is a key component in the Swedish reanimation of the Santiago pilgrimage. 